\title{
EVALUATING CHRONIC METAL OVEREXPOSURE IN CHILDREN
}

\author{
E.Blaurock-Busch* $\mathrm{PhD}$ \\ ebb@microtrace.de
}

* Lecturer and Advisor, International Board of Clinical Metal Toxicology, Hersbruck, Germany.

\begin{abstract}
Studies have linked metal overexposure in children with pollution and their immediate environment. Serious health issues have been reported in regions were natural geological factors and/or the mining industry contributed to a high metal exposure. Researchers could relate pollution to paediatric health problems, but geological issues and regional differences were rarely addressed. Hair mineral analysis (HMA) determines chronic metal exposure and thus, we compared the hair mineral concentration of various groups of children living in different regions of the world to evaluate if geological habitats or industrial sources could explain the groups' differences in metal exposure.
\end{abstract}

Keywords: hair analysis, chronic metal exposure, metal intoxication, pollution

\section{Introduction}

\subsection{Prevalence and types of metal exposure}

Metal Toxicology concerns itself with the mechanism and health effects of metals. Worldwide, geogenic, industrial, agriculture, and pharmaceutical sources are affecting populations, including children. Those living in Asia and Africa are more affected by acute metal intoxications than those residing in Europe. The prevalence and types of metal intoxication vary in different parts of the world and depend on industrial development, agricultural activities, cultural practices relating to supervision of children and local beliefs and customs. Risk factors for metal poisonings include those related to the metal itself, such as storage; season and weather conditions; policies, standards and laws governing the manufacture, distribution, storage, and disposal. To complicate matters, access to quality health care varies from country to country, affecting children's health.

Acute metal intoxication have been commonly found among 'gold washers' or in families of agricultural workers of India who acutely exposed themselves to arsenic - and remain to do so. Another source of metal poisoning are heavily industrialized areas such as polluted Mexico City(Calderon 2001), or the use of arsenicbased drugs used in treating certain tropical diseases such as African sleeping sickness and amoebic dysentery (Centeno et al 2005).

Western populations are less threatened by acute poisonings, but there is a rising concern about environmentally induced, chronic exposures caused by relatively low levels of toxic metals as found in the atmosphere, water, soil, and food. Children are increasingly affected, suffering from a variety of ailments that can be traced to chronic metal exposure. (Blaurock-Busch et al 2014; 2015; Bradl 2002; Ferguson 1990),) Those living in countries where 
metal pollution is of concern must be protected and through this work, we tried to identify those most affected.

Chronic metal-induced toxicity involves many mechanistic aspects, some of which are not clearly elucidated or understood. While each metal is known to have unique features and physic-chemical properties that confer to its specific toxicological mechanisms of action and its toxic effect on health, a metal's toxic effect also relates to dose per kilogram of bodyweight and metabolic function. Children are susceptible to metal overexposure, because of their smaller body size and their less well-developed physiology. To complicate matters, individuals who are 'lightly' exposed to more than one potentially toxic element, rarely display typical symptoms. For example, Agyria is a typical symptom of skin discoloration that appears after overuse of medicinal silver preparations. An individual who was lightly exposed to silver may not show any skin discoloration. Anemia is a known symptom of an acute lead intoxication, a low-grade lead exposure may not cause a quick onset of the disease, the process may only be delayed.

In general, light exposure to a multitude of potentially toxic metals may continue for weeks or months, increasing metal absorption into tissue, but without showing typical and easy to spot symptoms. Atypical, if not diffuse symptoms, complicate the diagnosis of a low-grade metal exposure. Through hair analysis, we tried to identify, which country's children are most at risk for developing environmentally caused disease.

\subsection{Biomonitoring metal exposure}

Biomonitoring a chronic metal overexposure is difficult. Blood or urine testing are the diagnostic methods of choice to identify an acute case of metal poisoning but may provide inconspicuous results in cases of a low-grade chronic metal exposure. Such daily low-grade exposure to a given metal may not significant enough to raise blood or urine levels above the reference range, yet most likely, the metal's effect starts taking place. Proving a case of overexposure can be a challenge.

When the body is unable to excrete toxins via normal routes, such as the renal or gastrointestinal system, the excess will be stored in human tissue. For example, cadmium is known to affect the renal system, lead is readily stored in bone, and elevated arsenic exposure in children has been associated with impaired neurological and immune function (Calderon et al. 2001; Wasserman et al., 2004). If blood and urine testing fail to identify a chronic metal exposure, chronic health problems may result.

\subsection{Tissue analysis}

In Labor und Diagnose, a German book on diagnostics, Thomas compares the storage of metals in tissues such as bone, brain, skin, muscle, liver, kidney, and hair. He indicates that lead or thallium are more readily stored in hair as in other body tissue. (Thomas 1992). Hair analysis has received wide attention, but it is not always favorably viewed. However, for the diagnosis of a chronic, low-grade metal overexposure in children, there are few alternatives. A biopsy of bone or brain tissue is usually not an option. Hair is a tissue, and hence an option.

\subsection{Hair Metal Analysis}

In forensic science, hair analysis has been used since 1930, at which time the forensic scientist Edmond Locart (1877-1966) introduced the Locart Exchange Principle, which basically states that "every contact leaves a trace." (Kirk 1953) Hair analysis detects traces left through drug abuse or 
metal overexposure. For decades now, hair analysis has been utilized to provide such information, but hair metal analysis remains controversial, largely due to the fact that laboratories providing this test disagree on important issues, such as the analytical process (i.e. washing the sample) and data interpretation. (Shamberger 2002)

The author has been actively involved in hair mineral analysis research since 1984. She has been instrumental in the development of protocols for hair metal testing, including the development of reference ranges for children and adults.

\section{Method}

\subsection{Analytical Procedure}

The analyses for this project was performed via inductively coupled plasma with mass spectrometry (ICP-MS) utilizing collision/reaction cell methods coupled with ion-molecule chemistry, a reliable new method for interference reduction. Certified hair standards and in-house standards were used as part of the laboratory quality control and for the validation of results.

\subsection{Sampling Procedures}

Hair samples had been taken from children age 5 to 12 years of age. Specimen had been submitted by clinics and academic institutions of various countries.

\section{Results}

Test results are given in mcg/g. At present, state agencies do not provide reference ranges (RR) for metals in hair, thus laboratories providing hair mineral analysis (HMA) develop their own ranges. Micro Trace Minerals has performed HMA since 1984 and developed HMA reference ranges for adults and children, following standard laboratory procedures. The children's hair reference ranges are largely based on samples from healthy European
Hair samples had been cut $3-5 \mathrm{~cm}$ from the scalp and shipped to the German laboratory Micro Trace Minerals $\mathrm{GmbH}$, for the detection of heavy metals and trace elements.

\subsection{Sample Size}

In the laboratory, samples were washed with non-ionic detergents and rinsed with ultrapure water before drying in a special, designated oven. The washed and dried hair was weighed close to $100 \mathrm{mg}$ before it was acid digested with non-ionic nitric acid.

Ultrapure water was used for the final sample dilution.

\subsection{Quality Control}

For quality control, the same procedure involving instrument calibration was used as for metal testing of water, blood, urine, and other tissue. Similarly, the use of internal standards certified control materials (including certified hair standard solution) was used

Micro Trace Minerals Laboratories routinely engages in quality assessment schemes. For hair, the Institute national de santé publique of Quebec's Multielement External Quality Assessment Scheme (QMEQAS) is utilized.

and US children, representing a 95 Percentile.

For ten groups of children, we evaluated and compared the metal exposure for the potentially toxic elements Arsenic (As), Barium (Ba), Cadmium (Cd), Lead $(\mathrm{Pb})$, Nickel (Ni), Thallium (Tl) Silver (Ag), Uranium (U) and Vanadium (V). We also included the nutrient metals Cobalt (Co), Copper ( $\mathrm{Co})$ and Iron $(\mathrm{Fe})$ since excessive exposure to these elements is known to create toxic effects. (Kennedy 2016; Rozman 1998) 


\subsection{Statistics and Data Analysis}

Test results were compared to the children's hair RR established by Micro Trace Minerals. Test results exceeding the established reference ranges for hair are considered pathological. For this project, the percentage of test results exceeding RR was determined and is listed in Table $1 . \mathrm{N}$ $=$ the number of participants for each group. The largest group consisted of German children (N762), the smallest group of children included here are Italians (N37). Not listed are test results for elements providing insignificant findings i.e. where $<5 \%$ of tests exceeded the hair RR.

Table 1: Percentage of Pathological Test Results

\begin{tabular}{|c|c|c|c|c|c|c|c|c|c|c|c|c|}
\hline & $A s$ & $A g$ & $B a$ & $C d$ & Co & $C u$ & $\mathrm{Fe}$ & $P b$ & $\mathrm{Ni}$ & $T l$ & $U$ & $V$ \\
\hline $\begin{array}{l}\text { Italian } \\
\text { N37 }\end{array}$ & & $\begin{array}{l}10 . \\
8\end{array}$ & & & & & & & & & $\begin{array}{l}10 . \\
8\end{array}$ & 8.1 \\
\hline $\begin{array}{l}\text { Spanish } \\
\text { N97 }\end{array}$ & & & & & & 32 & & & & & $\begin{array}{l}10 . \\
3\end{array}$ & $\begin{array}{l}53 . \\
6\end{array}$ \\
\hline $\begin{array}{l}\text { French } \\
\text { N125 }\end{array}$ & & & & & & $\begin{array}{l}13 . \\
6\end{array}$ & & & & & & \\
\hline $\begin{array}{l}\text { Germa } \\
\text { n N762 }\end{array}$ & & & & & & $\begin{array}{l}18 . \\
8\end{array}$ & & $\begin{array}{l}10 . \\
1\end{array}$ & & & 9.8 & \\
\hline $\begin{array}{l}\text { Austral } \\
\text { ian } \\
\text { N570 }\end{array}$ & & $\begin{array}{l}18 . \\
7\end{array}$ & & & 6.0 & 56 & $\begin{array}{l}12 . \\
3\end{array}$ & & & & & 19 \\
\hline $\begin{array}{l}\text { Nigeria } \\
\text { n N42 }\end{array}$ & 19 & & $\begin{array}{l}73 . \\
8\end{array}$ & $\begin{array}{l}54 . \\
8\end{array}$ & $\begin{array}{l}35 . \\
7\end{array}$ & $\begin{array}{l}16 . \\
7\end{array}$ & 90 & $\begin{array}{l}95 . \\
2\end{array}$ & $\begin{array}{l}40 . \\
5\end{array}$ & $\begin{array}{l}16 . \\
7\end{array}$ & & \\
\hline $\begin{array}{l}\text { Hongk } \\
\text { ong } \\
\text { N209 }\end{array}$ & & & & & & & & $\begin{array}{l}10 . \\
7\end{array}$ & $\begin{array}{l}18 . \\
7\end{array}$ & & & \\
\hline $\begin{array}{l}\text { Punjab } \\
\text { N237 }\end{array}$ & $\begin{array}{l}10 . \\
3\end{array}$ & $\begin{array}{l}13 . \\
5\end{array}$ & $\begin{array}{l}22 . \\
4\end{array}$ & $\begin{array}{l}14 . \\
3\end{array}$ & $\begin{array}{l}14 . \\
3\end{array}$ & & $\begin{array}{l}61 . \\
2\end{array}$ & 42 & & & $\begin{array}{l}41 . \\
8\end{array}$ & $\begin{array}{l}42 . \\
6\end{array}$ \\
\hline $\begin{array}{l}\text { Egyptia } \\
\text { n N194 }\end{array}$ & & & $\begin{array}{l}10 . \\
3\end{array}$ & 6.7 & 6.7 & & $\begin{array}{l}42 . \\
3\end{array}$ & 40 & $\begin{array}{l}11 . \\
3\end{array}$ & & & $\begin{array}{l}39 . \\
2\end{array}$ \\
\hline $\begin{array}{l}\text { Indones } \\
\text { ia } \\
\text { N62 }\end{array}$ & 11 & & & & & 29 & & & & & & $\begin{array}{l}12 . \\
9\end{array}$ \\
\hline
\end{tabular}

\subsection{Evaluation of Pathological Test Results} ARSENIC (As)

We tested isotope 75As. The hair RR for arsenic is $0.2 \mu \mathrm{g} / \mathrm{g}$. The statistical evaluation of 3126 kids of various nationalities showed that only $3.9 \%$ exceeded that range. For our regional test groups, the Nigerians showed the highest percentage of pathological tests results $(19 \%)$, followed by the Indonesians (11.3\%) and the Punjabis (10.1\%). All other groups showed insignificant results.
In 2012, Uhegbu et al reported high levels of arsenic in sea food from Niger delta where the children of our Nigerian group live. The inhabitants of this area depend on the river for fishing and other domestic uses. In addition, oil and gas related industries are located in this area known to discharge untreated waste products into rivers and soil. Similarly, arsenic pollution in coastal areas of Indonesia such as Buyat Bay of North Sulawesi caused high arsenic 
concentration in water and fish, creating health risks. (Musfirah 2016)

The Punjabi children may be exposed to arsenic through their water sources. Researchers of Punjab Agricultural University reported that the arsenic content of water samples collected from deep wells in homes varied in arsenic concentration from 9 to 85 parts per billion (ppb) with a mean value of $29.5 \mathrm{ppb}$. The World Health Organization and US Environment Protection Agency established a maximum contaminant level of $10 \mathrm{ppb}$ for arsenic in drinking water. (Singh 2012)

\section{SILVER (Ag)}

We tested 107Ag. The acceptable range for $\mathrm{Ag}$ in hair is $<1 \mu \mathrm{g} / \mathrm{g}$. The highest percentage of pathological results $(18.7 \%)$ was seen in the Australian group, the Punjabi group came second with $13.5 \%$, followed by the Italians with $10.8 \%$. Australia is third in the worldwide silver production after Mexico, Peru, and China. India is in 11th place. Overexposure to silver dust can result in agyria, a condition turning skin and other body tissues grey or blue grey. To our knowledge none of the children in our test groups showed these symptoms. Since silver has antibacterial functions, it is used in medicines and for water treatment.

\section{BARIUM (Ba)}

We tested isotope 138Ba. The hair RR is $<2.65 \mu \mathrm{g} / \mathrm{g}$. The Nigerians exceeded the RR with 73.8 percent of pathological tests, followed by the Punjabis with $22.4 \%$ and the Egyptians with $10.3 \%$.

Barium sulfate (the mineral baryte, BaSO4) is important to Nigeria's petroleum industry as a drilling fluid in oil and gas wells. In Punjab, Barium manufacturers are located.

CADMIUM (Cd)
We tested isotope $111 \mathrm{Cd}$. The hair $\mathrm{RR}$ is $0.2 \mu \mathrm{g} / \mathrm{g}$ hair. The Nigerians exceeded that RR with $54.8 \%$, followed by the Indian children of Punjab with $14.3 \%$ and the Egyptians with $6.7 \%$.

Prof. Orisakwe from the University of Port Harcourt Rivers State Nigeria, Port Harcourt Nigeria noted high Cd-blood levels in Nigerian children, indication of an acute and immediate exposure which may be attributed to industrial and environmental exposure. (Orisakwe 2014; Omawah 2013). If the exposure becomes chronic, hair levels will rise. Cadmium can be found in fertilizers, a problem noted in Punjab. Another source of cadmium is exposure to cigarette or other smoke.

COBALT (Co)

We tested isotope 59Co. The RR for this essential and potentially toxic element is $<0.15 \mu \mathrm{g} / \mathrm{g}$ hair. The Nigerian group was leading all other groups with $35.7 \%$, followed by the Punjabis with $14.3 \%$. The Australian showed $6 \%$ above the RR, the Egyptians $6.7 \%$.

Most of the cobalt in the world is mined in Africa, mainly Congo. In Nigeria and Punjab, cobalt industry is present, manufacturing and exporting cobalt.

\section{COPPER $(\mathrm{Cu})$}

We tested isotope $63 \mathrm{Cu}$. The upper hair RR of $37 \mu \mathrm{g} / \mathrm{g}$ hair was exceeded by the Australians by $56 \%$, followed by the Spanish with $32 \%$, the Indonesians by $29 \%$, the Germans by $18.8 \%$, the Nigerians by $16.7 \%$, and the French by $13.6 \%$.

Australia is a major copper producer with several mining and smelting operations. In Andalusia, Spain copper and iron had been mined for over 4,000 years. Indonesia is also known for its copper mines. On a smaller scale, copper has been mined in Germany and France. Copper ore has been one of the industrial minerals that have 
been mined in the Niger Delta, where our Nigerian test group comes from.

\section{IRON (Fe)}

We tested isotope $56 \mathrm{Fe}$. The Nigerian test results exceeded the RR of $15 \mathrm{mg} / \mathrm{g}$ hair by $90 \%$, followed by the Punjabis $(61.2 \%)$, the Egyptians with $42.3 \%$ and the Australians with $12.3 \%$.

Nigeria is among the African countries with vast iron ore deposits, initially discovered in the 1950s, after which time the Nigerian government began to actively plan strategies for local production of iron rods and steel. Water contamination is a notable environmental problem in the Niger Delta where the children came from. High iron levels have been located in Niger Delta river and streams. (Nduka 2011)

Ground water problems are considered the main reason for the iron overexposure seen in people of Punjab. Krishan of the National Institute of Hydrology and colleagues studied how iron levels in water fluctuated over time due to overgrazing, unplanned and unscientific deforestation. The researchers point out how iron is released into water and transported with sediments downslope, resulting in an unusually high iron content of the ground water that Punjabis use, unfiltered, for drinking. (Krishan 2015)

\section{LEAD $(\mathrm{Pb})$}

We tested isotope 208Pb. The upper RR for lead in hair is $3 \mu \mathrm{g} / \mathrm{g}$. The lowest percentage of pathological test results was seen in the German group $(10.1 \%)$, followed by $10.7 \%$ for the children of Hongkong. The highest percentage of pathological results was found in the Nigerian group with $95.2 \%$., followed by the Punjabi group with $42 \%$ and the Egyptians with $40 \%$.

Lead pollution remains a problem. In Nigeria, lead poisonings due to mining have been a problem for some time. Elisabeth Byrs, the spokeswoman for the UN's Organization for the Coordination of Humanitarian Affairs (OCHA) reported that in 2010, massive contamination affected 18000 Nigerians, more than 200 children died of lead poisoning, (BBC News, Sept. 21, 2010). The source of the poisoning was lead-contaminated waste dumped from illegal gold mining. Clean up operation followed, involving the removal of tons of contaminated topsoil. Our results indicate that lead overexposure remains a problem.

Lead pollution is still battled in Egyptia, due to industrialization and traffic. Furthermore. Egypt's sunny and dry climate (with about $22 \mathrm{~mm}$ rain annually) promotes pollution problems, but with the enactment of Cairo's Air Improvement Project (CAIP) harmful emissions from lead smelters and vehicle exhaust are gradually reduced. (Middle East Institute 2011)

In Punjab, crop burning remains an environmental issue. Also, dyeing units, chemical industries and electroplating units are said to be responsible for air and ground pollution. (SikhNet 2020)

NICKEL (Ni)

We tested isotope $60 \mathrm{Ni}$. The highest percentage of test values exceeding the RR of $0.85 \mu \mathrm{g} / \mathrm{g}$ hair was seen in the Nigerian group $(40.5 \%)$, followed by the children of Hongkong (18.7\%), and the Egyptians (11.3\%).

The Department of Civil Engineering at Landmark University, Kwara State, Nigeria reported that the levels of heavy metals such as lead found in the River Ijana of the Niger Delta were above WHO. standards recommended for surface waters. This 'water pollution' does affect children. (Owamah 2013). 
It may be assumed that the Nickel exposure of the Chinese and Egyptian children is environmentally-caused. Air pollution in Hongkong is considered a serious problem, and a large portion of this pollution comes from coal-fired power stations and vehicular traffic. Cairo suffers a similar problem. Cairo has been ranked as the second most polluted large city in the world.

\section{THALLIUM (Tl)}

We tested isotope 206Tl. Only the Nigerian group exceeded the upper RR (16.7\%). All other groups fell below $1.6 \%$.

Thallium is produced or used in power plants, cement factories, and smelters. Nigeria is known to have the oldest smelting sites of the world and we assume that the Nigerian children are exposed to thallium from coal-burning and smelting processes. The tiny particles can be inhaled or are consumed in food or drink.

\section{URANIUM (U)}

We tested isotope 238U. The Indian group exceeded all other groups by far with $41.8 \%$ of test results above the hair RR of $0.1 \mu \mathrm{g} / \mathrm{g}$. The Italian (10.8\%), Spanish (10.3\%) and German (9.8\%) followed while the percentage of pathological test values of all other groups was $<5.6 \%$.

In our previous Punjab studies on children with disabilities, $77 \%$ of that group showed hair concentration above the RR. (Blaurock-Busch et al 2010) Uranium and uranium waste is of concern to people in Punjab. Due to the geological formation of this state, Uranium is found in water and soil of certain regions, posing a potential risk.

As mentioned in yet another one of our Punjabi studies on cancer, uranium radiotoxicity or chemical toxicity can be caused by breathing air containing U-rich dust particles, especially in and around uranium mines and coal mines, or by eating substances containing $U$ or drinking U-containing water. Contaminated water from various areas in the Malwa region has been a source of controversy for years. Since 2009, various Indian governmental agencies, including the Bhaba Atomic Research Center have researched the $U$ concentration in water from the Malwa region. A study of water samples showed $\mathrm{U}$ concentrations ranging from 5.41 to $43.39 \mu \mathrm{g} / \mathrm{l}$ (Mehra et al., 2007), which must be considered high for certain areas. At present, the maximum contaminant level (MCL) is $30 \mu \mathrm{g} / \mathrm{l}$. In Canada, the MCL is set at $20 \mu \mathrm{g} / \mathrm{l}$. In Germany, the MCL is $10 \mu \mathrm{g} / \mathrm{l}$. The WHO and the American EPA (Environmental Protection Agency) are pushing for a zero level of uranium in drinking water.

High $U$ concentration has also been found in soil samples from the Malwa region around Faridkot (Mehra et al., 2006). Uranium is also considered an endocrinedisrupting chemical and in our previous study, we found an unusually high levels of uranium in hair of cancer and healthy patients, indicating that uranium overexposure should be of concern to Punjabis. (Blaurock-Busch 2014)

\section{VANADIUM (V)}

We tested isotope 51V. The highest percentage of test values above the RR of $0.15 \mu \mathrm{g} / \mathrm{g}$ hair was seen in the Spanish with $53.6 \%$, followed by the Punjabis (42.6\%), Egyptian (39.2\%), Australian (19\%) and the Indonesian with $12.9 \%$. Of the European groups, the Italians showed $8.1 \%$; all others were below $5 \%$.

Vanadium is widely distributed in nature, but not in its metallic form. It occurs in as many as 152 different minerals and fossil fuel deposits, like crude oil, coal, or tar sands. Vanadium is mined in three regions of Spain. During the first quarter of the 
20th century, the largest production worldwide was in Badajoz, Spain. Siemens is testing a vanadium flow battery at its La Plana R\&D site near Zaragoza.

\section{Discussion}

Nigerian children are excessively exposed to Arsenic, Barium, Cadmium, Cobalt, Copper, Lead, Nickel, Antimony, and Titanium, possibly due to Nigeria's key environmental issues relating to the petroleum industry, gas flaring, oil spillage resulting in water and vegetation problems. Furthermore, $90 \%$ of this group showed iron levels in hair above the high reference range. Certainly, when it comes to checking the iron status, blood tests are required, Hair only shows how much iron has been stored in hair tissue and this increased tissue supply may be due to an increased iron exposure. The region's iron ore mining may be the source. Since heavy metals such as lead are known to disrupt the iron metabolism and interfere with absorption, we recommend further studies of the Nigerian children's iron status, including the evaluation of serum iron, iron ferritin, transferrin and blood lead levels.

The second most exposed children are those of Punjab, India. As seen with the Nigerians, excessive lead exposure is seen in the Punjabi group and testing the iron status is also recommended for this group as it is for all those children exhibiting excessively high iron hair levels.

The third most exposed group are the Egyptian children, and we propose similar measures as outlined above.

For all overexposed children, we propose an investigation involving genetic testing of GSTT1 and GSTM1, the enzymes needed by the body to properly detoxify. Metals have the ability to disrupt enzyme function, an additional problem that must be addressed.

\section{Conclusion}

Through Hair mineral analysis (HMA) we could determine that the chronic metal exposure of children living in different regions of the world is influenced by geological habitats and more strongly by industrial i.e.chemical sources. Geological conditions may not be changed, but for the sake of our children, environmental problems can and must be dealt with.

\section{Acknowledgements}

No grants or financial support has been given for this study, but the author acknowledges and appreciates the assistance from Yvette M. Busch, CEO of Micro Trace Minerals Laboratory, Hersbruck, Ger,many.

\section{References}

Blaurock-Busch E et al. (2010) Metal exposure in the physically and mentally challenged children of Punjab, India. Maedica; Vol.5 No.2

Blaurock-Busch E et al. (2014) Comparing the Metal Concentration in the Hair of Cancer Patients and Healthy People Living in the Malwa Region of Punjab, India. Clin Med Insights Oncol; 8: 1-13.

Blaurock-Busch E et al. (2011) Heavy Metals and Trace Elements in Hair and Urine of a Sample of Arab Children with Autistic Spectrum Disorder. Maedica Vol. 6 No.4

Bradl H. (2002) Heavy Metals in the Environment: Origin, Interaction and Remediation Volume 6. London: Academic Press

Calderon J, Navarro ME, JimenezCapdeville ME et al. (2001) Exposure to arsenic and lead and neuropsychological development in Mexican children. Environ Research. 85:69-76.

Centeno JA, Tchounwou PB, Patlolla AK, Mullick FG, Murakat L, Meza E, Gibb H, 
Longfellow D, Yedjou CG. Environmental pathology and health effects of arsenic poisoning: a critical review. In: Naidu R, Smith E, Smith J, Bhattacharya P, editors. Managing Arsenic In the Environment: From Soil to Human Health. Adelaide, Australia: CSIRO Publishing Corp.; 2005.

Chamberlain G. (2009) India's generation of children crippled by uranium waste. The Telegraph. London. 30 August 2009

Fergusson JE, editor. (1990) The Heavy Elements: Chemistry, Environmental Impact and Health Effects. Oxford: Pergamon Press

Kirk PL. (1953) Crime investigation: physical evidence and the police laboratory. New York: Interscience Publishers, Inc.

Kayode OO, Odeniyi IA, Olopade OB, Iwuala SO, Odukoya OO, Fasanmade OA. (2019) Iodine status in pregnant Nigerian women; Does Gestational age matters? J Clin Sci 16:20-5

Kennedy D. et al. (2016) Environmental Toxicants and Infant Mortality in the USA. $\mathrm{J}$ of Biological Research and Development.pp 36-60

Krishan G. et al. (2015) Fluoride, Iron and Nitrate affected areas of Punjab. SGVU J CLIM CHANGE WATER Vol. 1 (1) Feb 2015 pp. 1-5 ISSN: 2347-7741

Marie PJ, Ammann P, Boivin G, Rey C. (2001) Mechanisms of action and therapeutic potential of strontium in bone. Calcif Tissue Int; 69: 121-9.

Musfirah SD. (2016) Arsenic Exposure to Fish and Shellfish Consumption among Community in Makassar, Indonesia. Int. J f Public Health Sci. Vol5. No.4: 437-443

Nduka JK, Orisakwe OE. (2011) Waterquality issues in the Niger Delta of Nigeria: a look at heavy metal levels and some physicochemical properties. Environ Sci Pollut Res Int. 2011 Feb;18(2):237-46. doi: 10.1007/s11356-010-0366-3. Epub 2010 Jul 8. PMID: 20607615.

Omawah HJ. (2013) Heavy Metals Determination and Assessment in a Petroleum Impacted River in the Niger Delta Region of Nigeria. J Pet Environ Biotechnol, 4:1

Omdahl JL, DeLuca HF. (1972) Rachitogenic activity of dietary strontium. I. Inhibition of intestinal calcium absorption and 1,25dihydroxycholecalciferol synthesis. J Biol Chem; 247: 5520-6.

Orisakwe OE. (2014) Lead and Cadmium in Public Health in Nigeria: Physicians Neglect and Pitfall in Patient Management. N Am J Med Sci. Feb; 6(2): 61-70.

Rozman KK, Doul J (1998) General principles of toxicology. In: Rose J, ed. Environmental Toxicology, Current Developments. First edition. Amsterdam: Gordon/Breach 1-11.

Schnug E, Lottermoser BG. (2013) Fertilizer-Derived Uranium and its Threat to Human Health. Environ. Sci. Technol. 47, 6, 2433-2434

Shamberger RJ. (2002)Validity of Hair Mineral Testing. Biol Trace Elem Res. 2;87(1-3):1-28.

Singh D. Hundal HS. Singh K. Arsenic content in ground and canal waters of Punjab - A paper by Punjab Agricultural University. India Waterportal 2012 (posted by Amita Bhaduri)

Thomas L. (1972) Labor und Diagnose. Med. Verlag Marburg, 4th Edition:430

Uhegbu, F.O., Chinyere, G.C., Ugbogu, A.E. et al. (2012) Arsenic and Chromium in Sea Foods from Niger Delta of Nigeria: A Case Study of Warri, Delta State. Bull Environ Contam Toxicol 89, 424-427

CONFLICT OF INTEREST: NONE 